\title{
HAMBATAN HAMBATAN UTAMA DALAM MANAJEMEN PENGELOLAAN SUNDAY MARKET KOTA MADIUN; PERSPEKTIF PEMERINTAH, PELAKU UMKM, DAN MASYARAKAT
}

\author{
*Itsna Rahmawati ${ }^{1)}$ \\ 1) Program Studi Ilmu Administrasi Negara Fakultas Ilmu Sosial dan Ilmu \\ Politik Universitas Sebelas Maret, Indonesia \\ *Email Korespondensi : itsnarahmawati@student.uns.ac.id
}

\begin{abstract}
Abstrak
Penelitian ini bertujuan untuk memetakan jenis-jenis hambatan dan dukungan dalam pengelolaan Sunday Market dan menjelaskan kaitan logis dengan sumber penyebab hambatan serta bentuk dukungan dari Perspektif Pemerintah, Pelaku UMKM, dan Masyarakat. Metode penelitian kualitatif bersifat deskriptif dengan pengambilan data berupa analisis observasi, dan wawancara dengan teknik purposive. Data dianalisis menggunakan analisis data Miles dan Huberman. Hasil analisis matriks SWOT diperoleh alternatif strategi pengembangan Pasar Sunday Market Kota Madiun antara lain yaitu, Strategi SO (Strength-Opportunities) Strategi SO ini dilakukan dengan optimalisasi Pembangunan dan revitalisasi pasar Sunday Market Kota Madiun dengan dilengkapi kemudahan akses bagi pengunjung maupun pedagang. Strategi ST (Strenghts-Threats) Adalah strategi promosi yang dilakukan dari mulut ke mulut atau melalui pamflet untuk mempromosikan kios untuk meningkatkan jumlah pengunjung serta mengadakan acara. Apabila jumlah pengunjung meningkat maka diharapkan jumlah calon pedagang akan meningkat. Strategi WO (Weknesses- Opportunities) Strategi yang digunakan adalah kerjasama Pasar Sunday Market Kota Madiun pedagang dan koperasi koperasi baik dari segi modal maupun input dan pemasaran produk. Pengembangan pasar Sunday Market Kota Madiun dengan melakukan kerjasama dengan investor.
\end{abstract}

Kata Kunci: Analisis SWOT; Perspektif Pemerintah, Pelaku UMKM, dan Masyarakat 


\begin{abstract}
This study aims to map the types of barriers and support in the management of the Sunday Market and explain the logical links to the sources of the causes of obstacles as well as forms of support from the perspectives of the government, SMEs and society. The qualitative research method is descriptive with data collection in the form of observation analysis, and interviews with purposive techniques. Data were analyzed using data analysis by Miles and Huberman. The results of the SWOT matrix analysis obtained an alternative strategy for the development of the Madiun Sunday Market Market, namely, the SO Strategy (Strength-Opportunities) The SO Strategy was carried out by optimizing the development and revitalization of the Madiun City Sunday Market market with easy access for visitors and traders. ST (Strenghts-Threats) Strategy Is a promotional strategy carried out by word of mouth or through pamphlets to promote kiosks to increase the number of visitors and hold events. If the number of visitors increases, it is expected that the number of prospective traders will increase. WO (Weknesses-Opportunities) Strategy. The strategy used is the cooperation of the Madiun City Market Sunday Market, traders and cooperative cooperatives, both in terms of capital and product input and marketing. Madiun City Sunday Market market development by collaborating with investors.
\end{abstract}

Keywords: SWOT analysis; Perspectives of Government, UMKM Actors, and Society

\title{
PENDAHULUAN
}

UMKM berperan strategis bagi pertumbuhan Ekonomi di Indonesia. Hal ini ditunjukkan dengan data perekonomian nasional tahun 2013-2014 yaitu, 5.440 triliun rupiah mampu disumbangkan UMKM, serta 114,14 juta orang terserap tenaga kerja, dan menarik 1.655,2 triliun rupiah investasi dengan total jumlah usaha sebanyak 57,8 juta unit. Untuk kontribusi Usaha Mikro, Kecil, dan Menengah (UMKM) di Indonesia tidak perlu diragukan lagi. Dominasi dunia usaha di Indonesia ditempati oleh UMKM yang menjadi level tinggi dan mampu menghadapi krisis, hal ini terlihat sejak adanya krisis ekonomi yang melanda bangsa Indonesia tahun 1998 silam, terbukti bahwa sektor UMKM lah yang masih mampu berdiri tegak bertahan dalam menghadapi krisis tersebut bahkan hingga saat ini. Dapat dilihat dari beberapa tahun terakhir penambahan unit UMKM dari tahun 2014-2018 mengalami peningkatan. (Salim et al., 2018)

Kota Madiun merupakan salah satu kota yang mendukung akan keberadaan Usaha Mikro, Kecil, dan Menengah (UMKM). Berdasarkan data, pada tahun 2017 ada sebanyak 23.276 pelaku UMKM. Sedangkan, pada 2018 sebanyak 23.360 pelaku UMKM, Dengan perincian 20.941 usaha mikro, 2.196 usaha kecil, dan 223 usaha menengah dengan menyerap sekitar 8.000 tenaga kerja dengan nilai produksi mencapai Rp65 miliar per tahun. Jumlah tersebut tersebar dalam berbagai sektor baik perdagangan, industri, maupun jasa. Jumlah pelaku UMKM di Kota Madiun merupakan yang terbanyak di wilayah karesidenan Madiun. Perkembangan UMKM yang baik di Madiun tidak terlepas dari dukungan pemerintah daerah Kota Madiun, hal ini 
ditunjukkan dengan adanya pasar minggu atau Sunday market dari yang diresmikan oleh pemerintah kota Madiun. Konsep Sunday Market sengaja dilakukan untuk mewadahi para pelaku UMKM guna meningkatkan perekonomian. Dengan adanya Sunday market diharapkan mampu menggerakkan masyarakat dan juga sebagai wadah para Pelaku UMKM dalam meningkatkan penghasilan, selain itu dengan adanya Sunday market juga diharapkan menjadi wadah yang bisa menarik pengunjung dan sebagai destinasi wisata baru yang akan di datangi dari masyarakat luar Kota Madiun.

Akan tetapi dari hasil wawancara pra observasi dari 15 orang pedagang yang berjualan di Sunday Market beberapa mengeluhkan mengalami penurunan Omzet, sementara itu dari hasil wawancara dari pengunjung pasar Sunday market beberapa dari pengunjung mengeluhkan lokasi di Taman Lalu Lintas Bantaran Kota Madiun jauh dari pemukiman dan kurangnya pepohonan yang menyebabkan suhu yang panas. Dari seluruh informasi yang diberikan oleh pemerintah, pedagang, dan masyarakat, untuk sementara peneliti melihat adanya ragam perspektif terkait penyelenggaraan CFD. Dari penjelasan tersebut nampak terdapat perbedaan pandangan antara pemerintah, pedagang, dan masyarakat tentang keberadaan Sunday market. Pemerintah memandang dengan adanya Sunday market pemerintah mengharapkan terciptanya antusias dari masyarakat serta adanya Sunday market dapat menjadi wadah para pelaku UMK dalam meningkatkan penghasilan, selain itu Sunday market juga diharapkan menjadi wadah yang bisa menarik pengunjung dan sebagai destinasi wisata baru yang akan di datangi dari masyarakat luar Kota Madiun. Sementara Pedagang berpandangan bahwa lokasi Sunday market di Taman Lalu Lintas Bantaran Kota Madiun kurang strategis dan menyebabkan penurunan omzet. Selain itu masyarakat memiliki pandangan lokasi Sunday market Kota Madiun sulit diakses oleh kendaraan karena kondisi jalan yang sempit.

Berdasarkan hasil Pra Survey di atas, maka ditemukan permasalahan yang perlu dikaji lebih lanjut. Permasalahan yang nampak saat ini adalah perbedaan perspektif antara pemerintah, pelaku UMKM, dan masyarakat. Jadi, penelitian ini akan menggali dan menjelaskan hambatan-hambatan utama dalam pengelolaan Sunday Market dari Perspektif Pemerintah, Pelaku UMKM, dan Masyarakat. Penelitian ini bertujuan untuk memetakan jenis-jenis hambatan dan jenis-jenis dukungan pengelolaan Sunday Market 
dan menjelaskan kaitan logis dengan sumber penyebab hambatan dari Perspektif Pemerintah, Pelaku UMKM, dan Masyarakat. Selain itu penelitian ini diharapkan dapat memberikan manfaat berupa memberikan tambahan evidence based policy dari kebijakan pengembangan Sunday market di kota Madiun yang dapat menjadi referensi bagi peneleti lain yang akan mengambil isu manajemen sektor perdagangan non formal. Memberikan masukan bagi pemerintah kota Madiun dan stakeholder terkait yang meliputi, pedagang Sunday market serta pengusaha kreatif dalam mengembangkan potensi dan meminimalisir hambatan pengembang Sunday market

\section{TINJAUAN PUSTAKA}

\section{Car freeday hingga Sunday market: bagian dari jenis pasar}

Car Free Day (CFD) adalah kegiatan lingkungan yang diselenggarakan untuk tujuan sosialisasi masyarakat agar dapat menurunkan ketergantungan masyarakat terhadap kendaraan bermotor, salah satu bentuk kegiatan Car Free Day adalah adanya penutupan jalan selama beberapa waktu dari arus lalu lintas kendaraan (Farda \& Balijepalli, 2018). Tujuan car free day menurut Kepmen LH No. 15/1996 melalui program Langit Biru yang melatarbelakangi munculnya kegiatan car free day di Indonesia.

Dengan adanya kegiatan Car Free Day diharapkan akan menjadi win win solusi dalam mengatasi berbagai permasalahan yang di temui di kota-kota di Indonesia baik di ibukota ataupun kota-kota lainnya dalam hal hal upaya pengurangan dampak dari emisi gas buang yang di keluarkan kendaraan bermotor. Tujuan utama dari di selenggarakanya carfree day ini adalah untuk mencegah/ mengurangi pencemaran udara utamanya yang ditimbulkan oleh kendaraan bermotor yang akan menimbulkan emisi gas buang sehingga berdampak berkurangnya kualitas udara serta lingkungan hidup. Dengan ditetapkannya peraturan pemerintah kota Madiun Nomor 3 Tahun 2014 dan Pelaksanaan car free day pertama kali di kota Madiun dilaksanakan pada tahun 2014, pelaksanaan car free day dilakukan secara rutin setiap hari minggu disepanjang jalan Pahlawan, Kota Madiun, dimulai pukul 05.00 WIB sampai pukul 09.00 WIB.

Namun demikian, disamping tujuan utama untuk lingkungan, car free day juga memiliki fungsi ekonomi dan fungsi rekreasi. Keduanya digabungkan potensian 
mendukung pengembangan ekonomi kreatif. Ekonomi kreatif dengan menggerakan potensi UMK dan masyarakat supaya mendukung kesejahteraan kota. Dalam perkembangannya Car free day menampakkan wajah pasar. Definisi pasar menurut Kolter (2002:73) adalah lokasi fisik yang mempertemukan antara pembeli dan penjual dan melakukan aktivitas tukar barang dan jasa. Konsep pasar dirujuk dalam penelitian ini untuk memberi legitimasi bahwa lokus penelitian ini diihat dari bagian kebijakan pengembangan pasar, secara khusus tipe pasar kaget.

\section{Konsep Manajemen Pengelolaan Ekonomi}

Menurut (Superti, 2017) pengelolaan merupakan suatu tindakan yang diawali dengan langkah-langkah penyusunan guna memperoleh data, kemudian membuat sebuah perencanaan dari hasil proses penyusunan, membuat koordinasi untuk langkah tindakan, melaksanakan tindakan kegiatan, sampai dengan proses pengawasan serta penilaian. Menurut (Permana \& Baehaqi, 2018) pengelolaan dikategorikan menjadi tiga pengetian, yaitu :

1) Pengelolaan merupakan bagian dari suatu proses

2) Pengelolaan merupakan langkah kolektif pelaku manajemen atau pihak manajerial

3) Pengelolaan merupakan suatu seni ilmu.

Jadi dapat disumpukan bahwa manajemen pengelolaan merupakan suatu proses yang diawali dari perencanaan, pengorganisasian, pengawasan dan evaluasi untuk mencapai suatu tujuan yang telah ditentukan agar berjalan efektif dan efisien.

\section{Fungsi Pengelolaan}

Terdapat empat fungsi manajemen sebagai berikut (Ardiana et al., 2010) :

\section{1) Perencanaan (Planning)}

adalah proses untuk menentukan langkah-langkah tindakan dalam mencapai hasil yang diinginkan (Suleman et al., 2020).

2) Pengorganisasian (Organizing)

Adalah proses pengelompokkan aktivitas-aktivitas yang akan dilakukan, yang meliputi penetapan susunan struktur organisasi serta menetapkan kedudukan dan sifat hubungan antara masing-masing dari setiap unit kedudukan dan menjelaskan tugas dan fungsi-fungsi dari setiap unit yang ada dalam organisasi.

3) Penggerakan 
adalah keseluruhan usaha, yang meliputi strategi dan teknik yang digunakan dalam proses pendorong agar individu atau kelompok individu secara suka rela bekerja dengan maksimal serta efisien, efektif, dan ekonomis (Siagian, 2003)

4) Pengawasan (Controlling)

pengawasan merupakan salah satu tugas mutlak diselenggarakan oleh semua orang yang menduduki jabatan manajerial, mulai dari manajer puncak hingga para manajer rendah yang secara langsung mengendalikan kegiatan-kegiatan teknis yang diselenggarakan oleh semua petugas operasional (Siagian, 2003)

Merujuk kepada fungsi manajemen di atas, maka penelitian ini akan menggunakan tahapan fungsi manajemen perencanaan, pengorganisasian, penggerakan, dan pengawasan untuk mengidentifikasi permasalahan hambatan dalam pengelolaan pasar Sunday market dari perspektif pemerintah. Penelitian ini menggunakan konsep SWOT untuk mengidentifikasi potensi pengembangan pengelolaan pasar. Analisis SWOT merupakan instrumen analisis yang biasa digunakan-oleh pemerintah dalam mempertimbangkan beberapa kebijakan. Analisis SWOT berisi analisis kekuatan dan kelemahan internal, dipadukan dengan ancaman dan peluang eksternal untuk merumuskan strategi pengembangan. Tahapan analisis SWOT yaitu:

a. mengidentifikasi faktor internal yang mendukung dan yang tidak dalam mencapai tujuan kebijakan.

b. mengidentifikasi faktor eksternal yang mendukung dan yang tidak dalam mencapai tujuan kebijakan

Analisis SWOT dapat diterapkan dengan cara menganalisis dan memilah berbagai hal yang mempengaruhi keempat faktornya, kemudian menerapkannya dalam gambar matrik SWOT.

\section{Perspektif Pemerintah}

Pemerintah Kota Madiun dalam upaya meningkatkan perekonomian di Kota Madiun, dengan meresmikan beberapa sektor potensial dalam meningkatkan perekonomian kota Madiun, salah satu sektor yang mampu meningkatkan perekonomian daerah kota madiun yaitu sektor informal atau UMK. Adanya pasar Sunday market di kawasan bantaran kali di Kota Madiun, diniliai sebagai referensi 
liburan keluarga serta wisata kuliner bagi masayrakat madiun dan masyarakat kota lain yang sedang berkunjung ke kota Madiun. Hal ini ditunjukkan dengan langkah nyata pemerintah yang sudah memulai tahap pembangunan diantaranya pedestrian di sepanjang Jalan Pahlawan kota Madiun, Taman Sumber Umis, serta renovasi Alun-Alun Kota Madiun dengan penambahan panggung pertunjukan, dan Sentra Kuliner di jalan Rimba Darma.

Menurut (Susanto et al., 2018) peran pemerintah dalam perekonomian sangatlah penting, peran pemerintah dalam strategi pengeleloaan pasar antara lain yaitu untuk mendorong kembali posisi permintaan dan penawaran dalam pasar melalui kebijakan belanja dan investasi. Selain itu, untuk mengendalikan dampak sosial dan lingkungan, pemerintah berperan untuk menekan produk-produk yang membahayakan sosial dan lingkungan dengan kebijakan pajak. Pemerintah juga mengambil peranan dalam penyediaan barang-barang publik yang tidak diminati oleh sektor privat, sehingga tentunya membutuhkan sumber-sumber penerimaan. Selain itu peran pemerintah dalam ekonomi sejatinya dibagi menjadi tiga hal, yaitu untuk mengatasi adanya kegagalan pasar akibat pemenuhan kebutuhan pasar yang tidak optimal, termasuk didalamnya penyediaan barang publik, mengendalikan eksternalitas seperti munculnya dampak lingkungan akibat industri, serta mendorong kompetisi/persaingan pasar yang sehat.

Adapaun upaya pemerintah dalam strategi pemberdayaan UMK menurut (Muzaqi et al., 2020) antara lain:

1) Strategi Peningkatan Kemampuan Finansial berupa pemberian modal sementara.

2) Pengembangan Pemasaran

Terdapat dua cara dalam strategi pengembangan pemasaran, yaitu: Meningkatkan Akses Usaha Kecil Kepada Pasar dan upaya proteksi pasar, dalam hal ini pemerintah melakukan strategi dengan menetapkan $10 \%$ dari total anggaran pemerintah digunakan untuk mengkonsumsi produk-produk badan usaha kecil.

3) Pengembangan Sumber Daya Manusia yaitu melakukan pembinaan terhadap industri kecil melalui peningkatan kualitas sumber daya manusia secara rutin dan berkelanjutan 
4) Strategi pengaturan dan pengendalian yang meliputi pengaturan perijinan secara formal yang dikeluarkan oleh pemerintah untuk mengatur dan memantau perkembangan usaha kecil.

Selain memberikan sebagai peran pendukung kebijakan pemerintah juga memiliki peran negative dalam pengelolaan pasar, dalam hal ini hambatan-hambatan yang muncul akibat dari kebijakan pemerintah dalam strategi pemberdayaan UMKM antara lain:

1) Hambatan korupsi yang meliputi banyaknya pungutan liar terhadap usaha, masih banyaknya praktik suap sebagai sarana umum untuk mendapatkan kontrak dari pemerintah, serta menggunakan jaringan informal untuk mengatur kebijakan.

2) Hambatan infrastruktur yang meliputi besarnya tarif listrik dan air untuk kegiatan usaha, dan tingginya biaya pendaftaran dan izin usaha.

Kajian pustaka tersebut di atas digunakan dalam penelitian ini untuk mengidentifikasi apakah pemerintah kota Madiun juga menyadari hal-hal negatif dan positif tersebut sebagai hambatan dan peluang pengembangan.

\section{Perspektif Pelaku UMK}

Dari pengakuan salah seorang pedagang, selama ini pedagang hanya dikenai retribusi kebersihan Rp 500. Dari pengakuan tersebut juga memastikan bahwa para pedagang CFD tidak tergabung dalam paguyuban apa pun. Hal ini dikarenakan sistem yang diterapkan di CFD bagi pedagang adalah siapa yang cepat datang, dia yang dapat tempat. Para pedagang juga mengaku keberadaan CFD mampu meningkatkan pendapatan ekonomi warga. Fenomena meningkatnya jumlah pedagang di kawasan CFD di kota Madiun dalam hal ini timbul akibat tidak tersedianya lapangan pekerjaan bagi rakyat kecil yang tidak memiliki kemampuan untuk mencari pekerjaan demi mendapatkan pendapatan dalam memenuhi kebutuhan hidup sehari-hari.

Selain tidak tersedianya lapangan kerja, pertumbuhan pedagang di kawasan CFD di Kota Madiun dimungkinan karena semakin meningkatnya perkembangan perekonomian, yang berpengaruh terhadap pertumbuhan usaha di Kota Madiun, hal ini tentunya berakibat pada kondisi lingkungan sekitarnya, sehingga perlu adanya pengaturan dan pembinaan guna terciptanya kawasan yang aman, tertib, bersih dan sehat. 


\section{Perspektif Masyarakat: nilai ekonomis dan nilai hiuran/wisata dari pasar}

Berdasarkan hasil dari pengamatan dan wawancara dari salah satu pengunjung di Sunday market Kota Madiun, keberadaan Sunday Market cukup menyedot perhatian masyarakat untuk datang berolahraga, atau berbelanja, atau bahkan sekedar melihatlihat di Sunday market Kota Madiun. Hal ini dikarenakan Sunday market tak hanya menarik untuk dikunjungi, namun Sunday market dapat menjadi tempat yang tepat untuk para seniman muda di kota Madiun untuk menunjukkan kemampuan mereka. Hal ini terlihat dari seringnya diadakan acara hiburan berupa kegiatan senam sehat, panggung hiburan serta berbagai pentas seni dari beberapa mahasiswa kampus di wilayah kota madiun.

Tak hanya itu, beberapa info dari salah seorang pengunjung menyatakan bahwa kedepannya akan ada banyak pelaku usaha besar yang ada di Kota Madiun mengadakan acara-acara perusahannya di sunday market. Hal ini tentunya memberi peluang masyarakat bersosialisasi dan mendapatkan barang murah.

\section{METODE PENELITIAN}

\section{Jenis Penelitian}

Jenis penelitian yang digunakan dalam penelitian ini menggunakan metode penelitian kualitatif. Penelitian kualitatif dalam penelitian ini bersifat deskriptif. Deskriptif artinya data yang dikumpulkan adalah berupa kata-kata, gambar dan bukan angka-angka (Sugiyono, 2016).

\section{Lokasi Penelitian}

Peneliti memilih penelitian mengenai hambatan-hambatan utama dalam pengelolaan Sunday Market dari Perspektif Pemerintah, Pelaku UMKM, dan Masyarakat di Kota Madiun.

\section{Sumber Data}

Menurut (Sugiono, 2016), sumber data dalam penelitian adalah subjek darimana dapat diperoleh. Sumber data dalam penelitian ini mencakupi sumber primer dan sekunder.

\section{Data Primer}

Data ini diperoleh dari responden, informan, peristiwa, situasi dan kondisi, dan 
fakta yang ada dan ditemukan di lapangan. Data lapangan ini diperoleh melalui instrumen-instrumen seperti observasi dan wawancara. Data ini dijadikan data primer dalam penelitian. Adapun sumber data primer diperoleh dari:

a. Dinas Perdagangan

- Kepala Seksi Pedagang Kaki Lima

b. Pedagang Pasar Sunday Market

- Paguyuban Pedagang Pasar Sunday Market Kota Madiun

c. Pengunjung Pasar Sunday Market

- Pengunjung Pasar Sunday Market Kota Madiun

2. Data Sekunder

Data Sekunder merupakan data-data tertulis yang bukan diperoleh dari lapangan secara langsung. Data sekunder adalah data yang diperoleh dari studi kepustakaan yaitu pengumpulan data dengan mempelajari dan menganalisis sumber literature yang ada hubungannya dengan objek penelitian. Data yang dijadikan data sekunder dalam penelitian ini meliputi data mengenai kebijakan dan implementasi kebijakan Pemerintah Kota Madiun terkait Sunday market dan yang relevan, Perda Kota Madiun, data pedagang pasar Sunday Market Kota Madiun, arsip Paguyuban Pedagang Pasar Sunday Market Kota Madiun, catatan-catatan dan foto-foto dari pemberitaan media tentang Sunday Market.

\section{Teknik Pengumpulan Data}

Teknik pengumpulan data dalam penelitian ini menggunakan:

1. Daftar Pertanyaan/Kuisioner

Kuisioner adalah pengumpulan data dan informasi terhadap narasumber yang dilakukan dengan lembar wawancara tertulis untuk mendapatkan jawaban atau tanggapan dari responden terkait objek penelitian.

2. Wawancara

Wawancara adalah teknik tanya jawab dengan pihak-pihak terkait penelitian guna menjaring data yang tidak diperoleh dari daftar pertanyaan/kuesioner dan data sekunder yang dilakukan dengan mengadakan tanya jawab langsung dengan pihak-pihak yang berkepentingan dalam penelitian.

3. Studi Lapangan (Observasi) 
adalah suatu kegiatan untuk dapat memasuki wilayah penelitian dengan maksud agar dapat diperoleh data primer yang dapat dicermati dan dicatat langsung oleh peneliti.

4. Analisis data pemerintah daerah Madiun terkait Pasar Sunday Market Kota Madiun

\section{Teknik Analisis Data}

Dalam penelitian ini menggunakan metode Analisis data Miles dan Huberman (Miles et al., 2018) yaitu aktivitas dalam analisis data kualitatif dilakukan secara interaktif dan berlangsung secara terus menerus sampai tuntas, sehingga datanya sudah mulai jenuh. Kegiatan analisis data dimulai dengan berikut ini:

\section{Reduksi Data (Data Reduction)}

Reduksi data adalah analisis data yang dilakukan dengan memilih hal-hal yang pokok, mendiskusikan pada hal-hal yang penting, dicari tema dan polanya (Miles et al., 2018)

Analisis data pada penelitian ini menggunakan Analisis SWOT. Analisis SWOT berisi analisis kekuatan dan kelemahan internal, dipadukan dengan ancaman dan peluang eksternal untuk merumuskan strategi pengembangan. Tahapan analisis SWOT yaitu:

a. mengidentifikasi faktor internal yang mendukung(kekuatan) dan yang menghambat(kelemahan) dalam penyelenggaraan Sunday market kota Madiun. Faktor internal dalam penelitian ini digali dari Dinas Perdagangan bidang Perdagangan dan Pasar.

b. mengidentifikasi faktor eksternal yang mendukung(peluang) dan yang kurang mendukung(tantangan) dalam penyelenggaraan Sunday market kota Madiun. Faktor eksternal dalam penelitian ini digali dari Pelaku UMKM maupun masyarakat.

\section{Penyajian Data (Data Display)}

Penyajian data berguna untuk memudahkan peneliti melihat gambaran secara keseluruhan atau bagian tertentu dari penelitian

3. Conclusion drawing/verification

Penarikan kesimpulan yaitu melakukan verifikasi secara terus menerus sepanjang 
proses penelitian berlangsung

Kesimpulan dirumuskan dengan mengacu pada jawaban permasalah penelitian yaiu:

1. Hambatan pengembangan Sunday market dari perspektif pemerintah, pedagang, dan masyarakat

2. Dukungan pengembangan Sunday market dari perspektif pemerintah, pedagang, dan masyarakat

Dari deskripsi hambatan dan peluang, ditarik kesimpulan alternatif strategi pengelolaan Sunday market, yang dipergunakan sebagai saran dari penelitian ini.

\section{HASIL DAN PEMBAHASAN}

Dari hasil wawancara yang dilakukan oleh peneliti kepada pihak dinas, pedagang serta paguyuban dan juga pengunjung, maka analisis SWOT pengelolaan Pasar Sunday Market Kota Madiun adalah sebagai berikut:

1. Strengths (Kekuatan) Merupakan faktor-faktor internal positif yang berperan terhadap kemampuan Pasar Sunday Market Kota Madiun dengan segala keunggulan yang dimiliki untuk mempertahankan posisinya untuk mencapai tujuannya. Faktor faktor tersebut adalah:

a. Mempunyai payung hukum atau legalitas yang jelas yakni Peraturan Daerah No. 13 tahun 2017 tentang penataan dan pembinaan toko swalayan dan pusat perbelanjaan serta pasar rakyat

b. Lokasi yang strategis di pusat Kota Madiun

c. Mempunyai petugas keamanan dan kenyamanan penjual dan pembeli

d. Adanya pengelolaan sampah

e. Mempunyai area yang luas

2. Weakness (Kelemahan) Merupakan faktor faktor internal negatif yang menghalangi kemampuan Pasar Sunday Market Kota Madiun terhadap sesuatu yang tidak dilakukan dengan baik atau tidak memiliki kapasitas untuk melakukannya, sementara para pesaingnya memiliki kapasitas tersebut untuk mencapai tujuannya. Faktor faktor tersebut adalah:

a. Kurangnya kesadaran pengunjung dalam membuang sampah

b. Tidak optimalnya akses air untuk para pedagang 
c. Akses masuk lokasi yang kurang

d. Minimnya fasilitas peneduh pengunjung

3. Opportunities (peluang) Merupakan faktor-faktor eksternal positif yang dapat dimanfaatkan oleh Pasar Sunday Market Kota Madiun karena hal yag mengguntungkan yang dapat meningkatkan kinerja untuk mencapai tujuannya. Faktor faktor tersebut adalah:

a. Satu-satunya pasar dengan konsep Car Free Day di Eks-Karesidenan Madiun

b. Antusias masyrakat terhadap pasar

c. Pemberitaan di media, baik cetak maupun online

4. Threats (ancaman) Merupakan segala macam bahaya yang sedang dihadapi maupun yang akan dihadapi oleh Pasar Sunday Market Kota Madiun. Faktorfaktor tersebut adalah:

a. Ditiru oleh wilayah kabupaten lain dan kehilangan atau berkurangnya pelanggan karena berpindah kepada pesaing lain.

b. Ancaman naiknya inflasi dan kondisi pandemi. Mengakibatkan daya beli masyarakat turun. Sehingga masyarakat lebih memilih berhemat memasak dirumah daripada membeli di rumah makan. Dan jika ada ancaman inflasi pasti harus ada kenaikan harga di secara bertahap.

c. Pergeseran budaya dan perilaku masyarakat

Berdasarkan hasil analisis SWOT dapat diketahui faktor pendukung dan faktor penghambat dalam manajemen pengelolaan pasar Sunday market Kota Madiun, antara lain yaitu:

\section{Faktor-Faktor Pendukung}

Faktor pendukung diperoleh dari kekuatan dan peluang pasar Sunday market Kota Madiun, berikut adalah faktor pendukung:

a. Mempunyai payung hukum atau legalitas yang jelas yakni Peraturan Daerah No. 13 tahun 2017 tentang penataan dan pembinaan toko swalayan dan pusat perbelanjaan serta pasar rakyat

b. Lokasi yang strategis di pusat Kota Madiun

c. Mempunyai petugas keamanan dan kenyamanan penjual dan pembeli 
d. Adanya pengelolaan sampah

e. Mempunyai area yang luas.

f. Satu-satunya pasar dengan konsep Car Free Day di Eks-Karesidenan Madiun

g. Antusias masyrakat terhadap pasar

h. Pemberitaan di media, baik cetak maupun online

2. Faktor-Faktor Penghambat

Faktor-faktor penghambat diperoleh dari hasil analisis kelemahan dan ancaman yang dihadapi, sebagai berikut:

a. Kurangnya kesadaran pengunjung dalam membuang sampah

b. Tidak optimalnya akses air untuk para pedagang

c. Akses masuk lokasi yang kurang

d. Minimnya fasilitas peneduh pengunjung

e. Ditiru oleh wilayah kabupaten lain dan kehilangan atau berkurangnya pelanggan karena berpindah kepada pesaing lain.

f. Ancaman naiknya inflasi dan kondisi pandemi. Mengakibatkan daya beli masyarakat turun. Sehingga masyarakat lebih memilih berhemat memasak dirumah daripada membeli di rumah makan. Dan jika ada ancaman inflasi pasti harus ada kenaikan harga di secara bertahap.

g. Pergeseran budaya dan perilaku masyarakat.

Dari faktor faktor strengths, weakness, opportunities dan threats akan menciptakan strategi baru dan mengetahui apakah analisis SWOT yang di terapkan di Sunday Market Kota Madiun sudah sesuai dengan tujuan yang diinginkan. Strengths (kekuatan) dan opportunities (peluang) yang dimiliki Pasar Sunday Market Kota Madiun menciptakan strategi SO (strengths opportunities) yang dikenal juga dengan istilah strategi pertumbuhan agresif (growth orientedstrategy). Strengths (kekuatan) dan threats (ancaman) yang dimiliki Pasar Sunday Market Kota Madiun menciptakan strategi ST (strengths threats) yang merupakan strategi diversifikasi (produk/pasar). Weakness (kelemahan) dan opportunities (peluang) yang dimiliki oleh Pasar Sunday Market Kota Madiun menciptakan strategi WO (weakness opportunities) yang dikenal dengan strategi turn around. Weakness (kelemahan) dan threats (ancaman) merupakan strategi WT (weakness threats) merupakan strategi defensive (bertahan). 


\section{KESIMPULAN DAN SARAN}

\section{Simpulan}

Hasil analisis matriks SWOT diperoleh alternatif strategi pengembangan Pasar Sunday Market Kota Madiun sebagai berikut.

\section{Strategi SO (Strength-Opportunities)}

Strategi ini dibuat berdasarkan jalan pikiran perusahaan, yaitu dengan memanfaatkan seluruh kekuatan untuk merebut dan memanfaatkan peluang yang sebesar-besarnya. strategi ini untuk memperbarui manajemen Pasar Sunday Market Kota Madiun yang telah diterapkan dengan tujuan untuk memaksimalkan kegiatan antar pegawai atau pegawai dengan pedagang.

Strategi SO ini dilakukan dengan optimalisasi Pembangunan dan revitalisasi pasar Sunday Market Kota Madiun dengan dilengkapi kemudahan akses bagi pengunjung maupun pedagang. Dan pengembangan pasar Sunday Market Kota Madiun dengan memanfaatkan potensi dan ciri khas yang dimiliki.

\section{Strategi ST (Strenghts-Threats)}

Adalah strategi dalam menggunakan kekuatan yang dimiliki perusahaan untuk mengatasi ancaman, antara lain: promosi yang dilakukan dari mulut ke mulut atau melalui pamflet untuk mempromosikan kios untuk meningkatkan jumlah pengunjung serta mengadakan acara. Apabila jumlah pengunjung meningkat maka diharapkan jumlah calon pedagang akan meningkat.

\section{Strategi WO (Weknesses- Opportunities)}

Strategi ini diterapkan berdasarkan pemanfaatan peluang yang ada dengan cara meminimalkan kelemahan yang ada. Strategi yang digunakan adalah kerjasama Pasar Sunday Market Kota Madiun pedagang dan koperasi koperasi baik dari segi modal maupun input dan pemasaran produk.

Meningkatkan kualitas SDM untuk mendukung pengembangan dan revitalisasi pasar

Sunday Market Kota Madiun melalui pelatihan. Rekruitmen pegawai untuk mendukung revitalisasi pasar Sunday Market Kota Madiun. Pengembangan pasar Sunday Market Kota Madiun dengan melakukan kerjasama dengan investor.

\section{Strategi WT (Weknesses- Threats)}

Strategi ini berdasarkan pada kegiatan yang bersifat defensif dan berusaha Copyright@2020; Jurnal Mediasosian - pISSN: 2579-342X, elSSN: 2620- 5149| 61 
meminimalkan kelemahan yang ada serta menghindari ancaman, yaitu: penyuluhan yang diberikan seperti perlunya pengetahuan tentang menjaga kebersihan saat transaksi berlangsung, penataan produk yang menarik minat konsumen. Selain itu, adanya peningkatan pembinaan pedagang untuk merubah mindset dan mengenai promosi untuk menarik minat pengunjung/masyarakat.

\section{Saran}

Saran yang dapat diberikan penulis untuk strategi pengelolaan Pasar Sunday Market Kota Madiun antara lain adalah sebagai berikut:

1. Untuk pemerintah Kota Madiun untuk lebih mengoptimalkan lagi potensi yang dimiliki oleh Pasar Sunday Market Kota Madiun.

2. Untuk pengelola pasar, koordinasi dan komunikasi yang baik harus lebih terjalin untuk memaksimalkan program atau kegiatan yang sudah direncanakan sebelumnya.

3. Kepada pedagang, untuk lebih menjamin kualitas barang dagangan, sehingga pembeli tidak merasa dikecewakan dengan produk atau barang dagangan yang dijual.

4. Kepada masyarakat umum, untuk senantiasa berbelanja kebutuhan sehari-hari di pasar.

\section{DAFTAR PUSTAKA}

Ardiana, I., Brahmayanti, I. A., \& Subaedi, S. (2010). Kompetensi SDM UKM dan pengaruhnya terhadap kinerja UKM di Surabaya. Jurnal Manajemen Dan Kewirausahaan, 12(1), pp-42.

Farda, M., \& Balijepalli, C. (2018). Exploring the effectiveness of demand management policy in reducing traffic congestion and environmental pollution: Car-free day and odd-even plate measures for Bandung city in Indonesia. Case Studies on Transport Policy, 6(4), 577-590.

Miles, M. B., Huberman, A. M., \& Saldaña, J. (2018). Qualitative data analysis: A methods sourcebook. Sage publications.

Muzaqi, A. H., Pratama, M. R., \& Widodo, S. (2020). Strategi Peningkatan Kesejahteraan Sosial Penyandang Disabilitas Netra Melalui Kebijakan Ingklusif. Journal Publicuho, 3(3), 381-393.

Permana, A., \& Baehaqi, A. (2018). Manajemen Pengelolaan Lembaga Amil Zakat dengan Prinsip Good Governance. Al-Masraf: Jurnal Lembaga Keuangan Dan Perbankan, 3(2), 117-131.

Salim, Wilmar, Drenth, M., Humaira, A. N. S., Rifai, A., Handayani, R., \& Histiraludin, S. (2018). Access to Urban Services for Inclusive Development in Asia Country Monograph: Indonesia. Swedish International Centre for Local 
Democracy.

Siagian, S. P. (2003). Manajemen sumber daya manusia.

Sugiono, S. (2016). Metode Penelitian Kuantitatif, Kualitatif, dan R \& D. Bandung: Alfabeta.

Sugiyono. (2016). Metode Penelitian Kuantitatif, Kualitatif dan R\&B. PT. Alfabet.

Suleman, A. R., Revida, E., Soetijono, I. K., Siregar, R. T., Syofyan, S., Hasibuan, A. F. H., Silitonga, H. P., Rahmadana, M. F., Silalahi, M., \& Syafii, A. (2020). BUMDES Menuju Optimalisasi Ekonomi Desa. Yayasan Kita Menulis.

Superti, I. (2017). ANALISIS MANAJEMEN PENGELOLAAN PASAR TRADISIONAL GUNA MENINGKATKAN PENDAPATAN PEDAGANG KECIL DALAM PERSPEKTIF EKONOMI ISLAM (Studi Kasus Pasar Simpang Agung, Desa Simpang Agung, Lampung Tengah). UIN Raden Intan Lampung.

Susanto, D. A., Isharyadi, F., \& Ritonga, M. (2018). Manfaat Ekonomi Penerapan Standar Pada Usaha Kecil Menengah Menggunakan ISO Methodology. Jurnal Standardisasi, 19(1), 25-38. 